Vol. 1, No. 2, Seri B, Mei 2019, Hal 710-726
ISSN : 2656-3649 (Online)

http://jea.ppj.unp.ac.id/index.php/jea/issue/view/6

\title{
PENGARUH REGULASI, POLITIK ANGGARAN, PERENCANAAN ANGGARAN, SUMBER DAYA MANUSIA DAN PENGADAAN BARANG/ JASA TERHADAP PENYERAPAN ANGGARAN BELANJA PADA OPD PROVINSI SUMATERA BARAT
}

\author{
Rifka Ramadhani', Mia Angelina Setiawan' \\ ${ }^{1)}$ Alumni Jurusan Akuntansi Fakultas Ekonomi Universitas Negeri Padang \\ 2) Jurusan Akuntansi Fakultas Ekonomi Universitas Negeri Padang \\ *Korespondensi: rifkaramadhani01@gmail.com
}

\begin{abstract}
This study aims to prove empirically the effect of regulation, budget politics, budget planning, human resources and the procurement of goods/services on budget absorption. This research is classified as causative research. The population in this study are 39 Regional Organizations (OPD) of West Sumatra Province. The sample in this study used the Total Sampling method. The type of data used in this study is primary and secondary data. Data collection techniques using a questionnaire consisting of 4 respondents in each OPD so that the questionnaire distributed was 156 questionnaires. The analytical method used is Multiple Regression Analysis using the SPSS version 25.00 program. The result of the study showed regulation, budget planning and the procurement of good/services has a significant positive effect on budget absorption. However, budget politics and human resources have no effect on budget absorption.
\end{abstract}

Keywords: Budget Absorption; Regulation; Budget Politics; Budget Planning; Human Resources and Procurement of good/services.

How to cite (APA $6^{\text {th }}$ style)

Ramadhani, R. \& Setiawan, M. A. (2019). Pengaruh Regulasi, Politik Anggaran, Perencanaan Anggaran, Sumber Daya Manusia Dan Pengadaan Barang/Jasa Terhadap Penyerapan Anggaran Belanja Pada OPD Provinsi Sumatera Barat. Jurnal Eksplorasi Akuntansi, 1(2), Seri B, 710-726.

\section{PENDAHULUAN}

Anggaran suatu negara merupakan alat penggerak yang digunakan oleh pemerintah untuk menjalankan roda pemerintahan. National Committe on Govermental Accounting (NGGA), yang saat ini telah diubah menjadi Goverment Accounting Standards Board (GASB) menjelaskan bahwa anggaran adalah rencana operasi keuangan yang mencakup estimasi pengeluaran yang diusulkan dan sumber pendapatan yang diharapkan untuk membiayainya dalam periode waktu tertentu (Bastian, 2010: 191). Anggaran Pendapatan dan Belanja Daerah (APBD) merupakan wujud pengelolaan keuangan daerah yang ditetapkan setiap tahun dengan peraturan daerah, 
dalam Permendagri Nomor 21 tahun 2011 disebutkan bahwa segala bentuk Penerimaan Daerah maupun Pengeluaran Daerah harus dicatat dan dikelola dalam APBD.

Proses penyusunan anggaran sesuai dengan Undang-Undang Nomor 9 Tahun 2015 tentang Pemerintah Daerah dan Undang-Undang Nomor 33 Tahun 2004 tentang Perimbangan Keuangan antara Pemerintah Pusat dan Pemerintah Daerah menjadi dasar dalam pelaksanaan otonomi daerah. Dengan adanya Undang-Undang tersebut, pemerintah pusat memberikan kewenangan kepada pemerintah daerah dengan pemberian bantuan dana untuk menjalankan kewenangan tersebut. Penerapan undang-undang tersebut diharapan agar pemerintah mampu meningkatkan efektivitas dan efisiensi dalam menyelenggarakan pemerintahan yang lebih baik.

Penyerapan anggaran merupakan salah satu indikator yang menunjukkan keberhasilan program atau kebijakan yang telah dilakukan suatu pemerintah (Anfujatin, 2016). Rasio pada realisasi terhadap anggaran membuktikan telah terserapnya anggaran dalam berbagai program yang telah ditetapkan. Penyerapan anggaran yang dibahas pada penelitian ini adalah keberhasilan Pemerintah Daerah dalam merealisasikan anggaran sesuai dengan yang sudah ditetapkan didalam APBD.

Salah satu permasalahan dalam anggaran pemerintah adalah penyerapan anggaran yang cenderung rendah di awal tahun dan menumpuk di akhir tahun menyebabkan ketidakmerataan penyerapan anggaran (Suwarni, 2018). World Bank, 2015 juga menyebut bahwa negara-negara berkembang seperti halnya Indonesia mempunyai permasalahan yang seragam dalam penyerapan anggaran yang disebut "slow back-loaded", artinya penyerapan rendah pada awal sampai tengah tahun anggaran, namun melonjak memasuki akhir tahun anggaran. Rendahnya penyerapan anggaran merupakan masalah klasik, hal ini terus terjadi setiap tahunnya. Keterlambatan realisasi anggaran yang menumpuk di akhir tahun berdampak pada kualitas kinerja pemerintah. Permasalahan ini dapat menghambat proyek yang ada dan akhirnya menganggu laju pertumbuhan perekonomian didaerah tersebut (Iqbal, 2018).

Fenomena penyerapan anggaran belanja ini juga terjadi pada Organisasi Perangkat Daerah (OPD) Provinsi Sumatera Barat, sebagaimana yang disampaikan Ketua DPRD Sumatera Barat Arkadius Datuak Intan Bano kepada Wartawan Koran Padang Ekspres tanggal 23 Agustus 2018 bahwa dari hasil evaluasi yang dilaporkan oleh Pemprov rata-rata serapan anggaran masih pada angka 40 persen, serapan anggaran yang rendah akan berdampak negatif terhadap ekonomi. Selanjutnya Ketua DPRD meminta bahwa, Gubernur terus mengenjot kinerja OPD dalam penyerapan anggaran. Pasalnya dari hasil evaluasi semester I tahun 2018, serapan anggaran OPD masih rendah, yang seharusnya pada semester I atau Juni 2018, realisasi APBD pada OPD sudah mencapai 50 persen.

Diketahui bahwa pemerintah provinsi mencapai realisasi anggaran belanja dibawah $50 \%$. Tahun 2018, total anggaran belanja Pemerintah Provinsi Sumatera Barat sebesar Rp. 6.634.349.848.473 dan yang terealisasi hanya sebesar Rp. 2.265.998.908.503 atau sebesar 34,16\%. Data ini lebih rendah dibandingkan triwulan yang sama tahun 2017 yang mencapai $34,88 \%$ (KEKR, Provinsi Sumatera Barat). Gubernur Sumatera Barat Irwan Prayitno menyebutkan mengultimatum kepala OPD agar menyelesaikan realisasi anggaran minimal 95\% sampai November tahun ini, Irwan menyebutkan tidak segan mengganti pejabat OPD yang berkinerja buruk atau gagal mencapai realisasi anggaran tahun ini, minimal $95 \%$ (padang.bpk.go.id)

Namun kenyataannya hingga triwulan III tahun anggaran 2018 realisasi anggaran belanja Pemerintah Provinsi Sumatera Barat baru mencapai Rp. 3.463.974.152.960 dari target yang ditetapkan sebesar Rp. 6.895.649.672.146 atau baru mencapai 50,23 persen 
(dpkd.sumbarprov.go.id). Data ini menjelaskan bahwa daya serap anggaran belanja pemerintah Provinsi Sumatera Barat belum maksimal karena belum sesuai dengan target yang diinginkan.

Dari uraian diatas, Ketua DPRD dan Gubernur Sumatera Barat sangat menekankan pentingnya penyerapan anggaran yang optimal, karena berpengaruh terhadap tingkat pelayanan dan kesejahteraan masyarakat. Dan dapat diidentifikasi bahwa terdapat hambatan yang menyebabkan penyerapan anggaran tidak proporsional sesuai dengan rencana penarikan pertriwulannya, sehingga capaian progres yang ditetapkan tidak tercapai secara optimal.

Dalam penelitian ini ada beberapa faktor yang berpengaruh terhadap penyerapan anggaran yang pertama adalah faktor regulasi, dimana regulasi mengandung arti kaidah yang dibuat untuk mengatur petunjuk yang dipakai untuk menata sesuatu dan ketentuan yang harus dijalankan serta dipatuhi (Bastian, 2010: 33). Regulasi digunakan oleh organisasi publik untuk mewujudkan kebijakan organisasi dalam menghadapi isu dan permasalahan yang ada. Namun dikarenakan banyaknya aturan yang berubah secara cepat sementara waktu yang tersedia tidak terlalu banyak, sehingga dalam pelaksanaan anggaran mengalami kendala dalam pengimpelentasiannya dari suatu kegaiatan yang menyebabkan lambatnya penyerapan anggaran di instansi pemerintah.

Dalam penelitian Alimuddin (2018) menyatakan bahwa regulasi berhubungan positif dan berpengaruh signifikan terhadap penyerapan anggaran. Faktor penyebab ketidakmerataan penyerapan anggaran berkaitan dengan faktor regulasi karena regulasi yang ditetapkan oleh pemerintah pusat justru membuat penyerapan APBD di pemerintahan daerah mengalami ketidakmerataan. Oleh karena itu strategi yang dapat diberikan terkait pemasalahan pada regulasi tersebut salah satunya adalah dengan adanya kebijakan penyerapan anggaran, sehingga dengan adanya kebijakan tersebut penyerapan anggaran yang diperoleh dapat semaksimal mungkin (Salamah, 2018).

Senada dengan itu, hasil penelitian Ridani (2015) dan Widianingrum (2017) juga menemukan bahwa faktor yang mempengaruhi penyerapan anggaran, salah satunya disebabkan karena regulasi yang dilihat dari bagaimana pemahaman dan kepatuhan setiap pegawai mengenai peraturan yang ada. Akan tetapi, hasil penelitian yang menyebutkan bahwa faktor regulasi berpengaruh terhadap penyerapan anggaran tidak didukung oleh hasil penelitian Rifai (2016) yang menyatakan sebaliknya, bahwa regulasi tidak berpengaruh terhadap penyerapan anggaran. Oleh karena itu faktor regulasi terdapat ketidakkonsistenan hasil yang mempengaruhi faktor regulasi.

Faktor yang mempengaruhi penyerapan anggaran selanjutnya adalah faktor politik anggaran. Dimana anggaran yang digunakan untuk memutuskan prioritas-prioritas dan kebutuhan terhadap prioritas tersebut. Anggaran yang digunakan merupakan dokumen politik sebagai bentuk komitmen eksekutif dan kesepakatan legislatif atas penggunaan dana publik untuk kepentingan tertentu. Menurut (Mardiasmo, 2002: 65) anggaran bukan sekedar masalah teknis akan tetapi lebih merupakan alat politik (political tool).Anggaran publik tidak hanya proses teknis maupun manajerial tetapi juga ada bersifat politis. Anggaran menggambarkan pilihan tentang apa yang akan dan tidak akan dilakukan pemerintah, mereka memberikan jenis layanan apa yang harus diberikan oleh pemerintah kepada warga negara yang berhak menerimanya. Untuk itu pemerintah sebagai pelaksana layanan publik mempunyai kewajiban untuk memenuhi prioritas yang adil dan sesuai kebutuhan masyarakat.

Penelitian yang dilakukan Sanjaya (2018) menyatakan bahwa politik anggaran mempengaruhi penyerapan anggaran, dimana politik anggaran menunjukkan peranan pemerintah dalam mengatur pembelanjaan keuangan daerah sebagai salah satu kewajiban dalam 
menciptakan kesejahteraan masyarakat melalui penyerapan anggaran. Namun berbeda dengan penelitian sebelumnya yang dilakukan Handayani (2017) yang menyatakan sebaliknya bahwa politik anggaran tidak mempengaruhi penyeraan anggaran, sehingga terdapat ketidakkonsistenan hasil yang mempengaruhi faktor politik anggaran.

Faktor yang mempengaruhi penyerapan anggaran selanjutnya adalah faktor perencanaan anggaran, dimana perencanaan anggaran sendiri dapat diartikan sebagai suatu rancangan sebagai pengendali dan penentu arah yang akan ditempuh oleh suatu organisasi untuk mencapai suatu tujuan organisasi. Permasalahan yang timbul didalam perencanaan anggaran disebabkan karena konsep perencanaan yang tidak matang dalam penentuan anggaran berdampak kepada program kerja yang tidak berjalan sesuai dengan apa yang diinginkan. Selain itu, masalah yang terjadi pada perencanaan juga terjadi karena adanya anggapan anggaran yang diusulkan tidak semuanya akan disetujui. Akhirnya mengusulkan anggaran yang lebih besar dari yang dibutuhkan tanpa memikirkan kebutuhan rill yang ada di lapangan (Seftianova, 2013)

Faktor lemahnya perencanaan juga menjadi kendala pada saat pembuatan perencanaan yang menyebabkan penyerapan anggaran menjadi lambat. Dalam penelitian Iqbal (2018) juga menyebutkan faktor yang berpengaruh besar terhadap penyerapan anggaran adalah faktor perencanaan, karena semakin matang aparatur pemerinah sebagai pengelola anggaran dalam merencanakan maka kegiatan/program yang ditargetkan akan berjalan dengan baik pula.Hasil penelitian yang dilakukan Herriyanto (2012) juga sejalan dengan hasil penelitian yang dilakukan Malahayati (2015), Setyawan (2016), Zarinah (2016) dan Dwiyana (2017) yang menyatakan bahwa faktor perencanaan anggaran berpengaruh terhadap penyerapan anggaran. Namun berbeda dengan penelitian yang dilakukan oleh Rifai (2016) dan Halim (2018) yang menyatakan sebaliknya bahwa perencanaan anggaran tidak berpengaruh terhadap penyerapan angggaran.

Faktor berikutnya yang mempengaruhi penyerapan anggaran adalah sumber daya manusia, dimana Pegawai Negeri Sipil (PNS) sebagai aparat yang mengelola keuangan juga menjadi faktor penyerapan anggaran. Hal ini sesuai dengan penelitian Setyawan (2016) bahwa keterlambatan penyerapan anggaran belanja disebabkan faktor sumber daya manusia. Permasalahan sumber daya manusia yang mengelola keuangan di antaranya adalah kurangnya jumlah pegawai, adanya perangkapan pekerjaan, dan pola mutasi yang tidak merata.

Dalam penelitian Anfujatin (2016) permasalahan sumber daya manusia terjadi berawal dari rangkap tugas dalam panitia pengadaan, hal ini karena tidak seimbangnya antara paket pekerjaan dengan sumber daya manusia yang memenuhi kualifikasi sesuai dengan peraturan sehingga mengakibatkan belum optimalnya dalam penyerapan anggaran. Sumber daya manusia merupakan faktor yang menyebabkan keterlambatan penyerapan anggaran belanja. Beberapa penelitian sebelumnya juga menyatakan bahwa sumber daya manusia (SDM) berpengaruh pada penyerapan anggaran, yang dilakukan oleh Herryanto (2012), Putri (2014), Mutmainna (2017). Akan tetapi, hasil penelitian yang menyatakan bahwa faktor sumber daya manusia berpengaruh pada penyerapan anggaran ternyata tidak didukung oleh hasil penelitian Alumbida (2016), Nugroho (2017) dan Alimuddin (2018) yang menyatakan sebaliknya bahwa sumber daya manusia tidak mempengaruhi penyerapan anggaran.

Faktor berikutnya yang mempengaruhi penyerapan anggaran adalah pengadaan barang/jasa. Pengadaan barang dan jasa merupakan salah satu tugas organisasi sektor publik untuk memenuhi kebutuhan masyarakat (Bastian, 2010: 263). Dalam penelitian Priatno (2013) menjelaskan faktor pengadaan barang dan jasa mempunyai pengaruh yang signifikan terhadap penyerapan anggaran satuan kerja, faktor pengadaan barang dan jasa satuan kerja yang buruk dalam pelaksanaan kegiatan mempunyai kecenderungan memperlambat penyerapan anggaran 
satuan kerja. Senada dengan itu penelitian yang dilakukan oleh Setyawan (2016), Gogala (2016) dan Alimuddin (2018) juga menyatakan bahwa faktor yang mempengaruhi penyerapan anggaran disebabkan oleh faktor pengadaan barang/jasa. Namun lain halnya dengan penelitian yang dilakukan oleh Nugroho (2017) dan Sanjaya (2018) yang menyatakan sebaliknya bahwa pengadaan barang/jasa tidak mempengaruhi penyerapan anggaran.

Berdasarkan penelitian terdahulu masih terdapat ketidakkonsistenan hasil penelitian atas faktor-faktor yang mempengaruhi penyerapan anggaran sehingga peneliti merasa perlu menguji ulang variabel ini kembali dengan jumlah sampel dan periode waktu yang berbeda. Peneliti menggunakan periode yang terbaru yaitu tahun anggaran 2018 dengan jumlah sampel dan responden pada Organisasi Perangkat Daerah (OPD) Provinsi Sumatera Barat yang berbeda dengan penelitian sebelumnya. Karena adanya fenomena yang terjadi mengenai penyerapan anggaran belanja yang masih lambat dan tidak merata sampai akhir tahun. Sehingga peneliti ingin mengetahui apakah faktor regulasi, politik anggaran, perencanaan anggaran, sumber daya manusia dan pengadaan barang/jasa mempengaruhi penyerapan anggaran belanja, agar OPD di Pemerintah Provinsi Sumatera Barat dapat mengevaluasi hal-hal apa saja yang dapat ditingkatkan agar maksimal dalam penyerapan anggaran belanja.

Berdasarkan uraian diatas, maka penulis tertarik untuk melakukan penelitian dengan judul "Pengaruh Regulasi, Politik Anggaran, Perencanaan Anggaran, Sumber Daya Manusia dan Pengadaan Barang/Jasa Terhadap Penyerapan Anggaran Belanja Pada OPD Provinsi Sumatera Barat"

\section{REVIEW LITERATUR DAN HIPOTESIS \\ Teori Stakeholder}

Menurut Freeman dan Reed, 1983 dalam (Ulum, 2009: 04) Teori Stakeholder adalah "Any indentifible group or individual who can affect the achievement of an organization's objectives, or is affected by the achievement of an organization's objectives". Jadi teori stakeholder merupakan sekelompok orang atau individu yang diidentifikasikan dapat mempengaruhi dan dapat dipengaruhi oleh suatu pencapaian tujuan tertentu. Para pemegang saham, para supplier, bank, para customer, pemerintah dan komunitas yang memegang peranan penting dalam organisasi (berperan sebagai stakeholder).

Menurut Ghozali dan Chairiri (2007: 409) teori stakeholder merupakan teori yang menyatakan bahwa perusahaan bukanlah entitas yang hanya beroperasi untuk kepentingan sendiri, namun harus memberikan manfaat kepada seluruh stakeholder-nya contohnya seperti pemegang saham, kreditor, konsumen, supplier, pemerintah, masyarakat, analis, dan pihak lain. Dengan demikian, keberadaan suatu perusahaan atau orgainsasi sangat dipengaruhi oleh dukungan yang diberikan oleh stakeholder kepada perusahaan atau organisasi tersebut.

Sebagai stakeholder pemerintah memiliki peran penting dalam proses memajukan suatu daerah dan diharapkan mampu untuk melakukan pembangunan secara maksimal, yang sejalan dengan tujuan peningkatan kesejahteraan masyarakat. Kemajuan suatu daerah dilihat dari bagaimana pemerintah mampu mengelola anggaran yang ada untuk kepentingan rakyat didaerahnya. Tentu untuk mewujudkannya tidak mudah, oleh karena itu pemerintah dapat bekerja sama dengan masyarakat dalam menggunakan kewenangan, pelayanan dan strategi dalam menghadapi permasalahan yang terjadi didaerah. Sehingga dalam penggunaan anggaran dapat secara efektif, efesien dan ekonomis, penyerapan anggaran akan cepat dan terserap merata sampai akhir tahun. 


\section{Teori Anggaran}

Menurut Mardiasmo (2002:61), anggaran adalah sebagai sebuah proses yang dilakukan oleh organisasi sektor publik untuk mengalokasikan sumber daya yang dimilikinya pada kebutuhankebutuhan yang tidak terbatas. Selain itu, anggaran merupakan pernyataan mengenai estimasi kinerja yang hendak dicapai selama periode waktu tertentu yang dinyatakan dalam ukuran finansial. Anggaran merupakan artikulasi dari hasil perumusan strategi dan perencanaan strategi yang telah dibuat. Menurut Mardiasmo (2002:62), anggaran berisi estimasi mengenai apa yang akan dilakukan organisasi di masa yang akan datang. Setiap anggaran memberikan informasi mengenai apa yang hendak dilakukan dalam beberapa periode yang akan datang.

Sedangkan menurut Bastian (2006: 289) anggaran merupakan pernyataan tertulis berupa ukuran finansial mengenai estimasi kinerja masa depan yang hendak dicapai selama periode tertentu biasanya satu tahun. anggaran yang telah disusun akan dievaluasi pada akhir tahun untuk melihat apakah estimasi kinerja tersebut telah tercapai. Pencapaian kinerja merupakan ukuran prestasi kerja organisasi publik yang akan dicapai, dan diukur dalam bentuk kualitas, kuantitas, efisiensi dan efektivitas pelaksanaan dari setiap program dan kegiatan.

\section{Belanja Pemerintah Daerah}

Berdasarkan Permendagri No. 21 Tahun 2011 tentang Pedoman Pengelolaan Keuangan Daerah, belanja menurut kelompok belanja terdiri dari:

a. Belanja tidak langsung merupakan belanja yang dianggarkan tidak terkait secara langsung dengan pelaksanaan program dan kegiatan. Kelompok belanja tidak langsung dibagi menurut jenis belanja yang terdiri dari belanja pegawai, bunga, subsudi, hibah, bantuan sosial, belanja bagi hasil, bantuan keuangan, dan belanja tidak terduga.

b. Belanja langsung merupakan belanja yang dianggarkan terkait secara langsung dengan pelaksanaan program dan kegiatan. Kelompok belanja langsung dibagi menurut jenis belanja yang terdiri dari belanja pegawai yang dimaksudkan untuk pengeluaran honorarium/ upah dalam melaksanakan program dan kegiatan pemerintah daerah; belanja barang dan jasa; dan belanja modal

\section{Teori Penyerapan Anggaran}

Menurut Halim (2014: 84), bahwa penyerapan anggaran adalah pencapain dari suatu estimasi yang hendak dicapai selama periode waktu tertentu yang dipandang pada suatu saat tertentu (realisasi dari anggaran). Secara lebih mudah, masyarakat umum menyebutnya pencairan anggaran. Oleh karena yang diamati adalah entitas pemerintahan atau organisasi sektor publik, maka penyerapan anggaran dapat diartikan sebagai pencairan atau realisasi anggaran sesuai yang tertera dalam Laporan Realisasi Anggaran (LRA) pada saat tertentu.

Senada dengan pendapat Halim, menurut Kuncoro (2013) bahwa penyerapan anggaran adalah salah satu dari beberapa tahapan dalam siklus anggaran yang dimulai dari perencanaan annggaran, penetapan dan pengesahan anggaran oleh Dewan Perwakilan Rakyat/Daerah (DPR/DPRD), penyerapan anggaran, pengawasan anggaran dan pertanggungjawaban anggaran.

\section{Hubungan Regulasi dengan Penyerapan Anggaran}

Regulasi publik adalah ketentuan yang harus dijalankan dan dipatuhi dalam proses pengelolaan organisasi publik, baik pada organisasi pemerintah pusat, pemerintah daerah, partai politik, yayasan, LSM, organisasi keagamaan, maupun organisasi sosial lainnya (Bastian, 2010: 33). Permasalahan regulasi ini terkait dengan peraturan pemerintah pusat maupun peraturan daerah, 
dimana permasalahannya terjadi mengenai pergantian regulasi, sehingga perubahan regulasi terjadi menyebabkan penyerapan anggaran menjadi terganggu.

Hasil penelitian Alimuddin (2018) menemukan hubungan yang positif dan signifikan antara regulasi dengan penyerapan anggaran. Sejalan dengan hasil penelitian Ruwaida (2015), Widianingrum (2017) dan Salamah (2018) yang menyatakan bahwa faktor regulasi berpengaruh terhadap penyerapan anggaran. Berbeda dengan Rifai (2016) yang menunjukkan bahwa regulasi tidak berpengaruh terhadap penyerapan anggaran. Berdasarkan ketidakkonsistenan hasil penelitian yang telah ada maka penelitian ini kembali dilakukan dengan tujuan untuk menguji kembali pengaruh regulasi terhadap penyerapan anggaran, maka dapat dirumuskan hipotesis sebagai berikut :

H1: Regulasi berpengaruh positif terhadap penyerapan anggaran

\section{Hubungan Politik Anggaran dengan Penyerapan Anggaran}

Anggaran digunakan untuk memutuskan prioritas-prioritas dan kebutuhan keuangan terhadap prioritas tersebut. Pada sektor publik, anggaran merupakan alat politik (political tool) sebagai bentuk komitmen eksekutif dan kesepakatan legislatif atas penggunaan dana publik untuk kepentingan tertentu (Mardiasmo, 2002).Apabila dalam pelaksanaan anggaran tidak sesuai dengan kepetingan politik atau pelaksanaan yang diajukan tidak sesuai dengan prioritas yang telah disepakati bersama, maka secara tidak langsung dapat memperlambat waktu kegiatan/program kerja. Hal ini membuktikan bahwa politik anggaran berpengaruh positf terhadap penyerapan anggaran, apabila kebutuhan politik terpenuhi maka penyerapan anggaran akan lebih mudah dicapai, ini disebabkan karena setiap anggaran yang diajukan oleh pemerintah sesuai dengan prioritas disepakati bersama dan disetujui eksekutif.

Hasil penelitian Sanjaya (2018) menemukan hubungan yang positif dan signifikan antara politik anggaran dengan penyerapan anggaran. Berbeda dengan Handayani (2017) yang menunjukkan bahwa politik anggaran tidak berpengaruh terhadap penyerapan anggaran. Karena ketidakkonsistenan hasil penelitian yang telah ada maka penelitian ini kembali dilakukan dengan tujuan untuk menguji kembali pengaruh politik anggaran terhadap penyerapan anggaran. Sehingga dapat dirumuskan hipotesis sebagai berikut :

$\mathrm{H} 2$ : Politik anggaran berpengaruh positif terhadap penyerapan anggaran

\section{Hubungan Perencanaan Anggaran dengan Penyerapan Anggaran}

Menurut Arif dan Halim, 2013 (dalam Iqbal, 2018) bahwa semakin matang pengelola anggaran dalam merencanakan, maka program kerja/kegiatan dalam satu tahun anggaran akan berjalan dengan baik, sehingga target penyerapan anggaran dapat tercapai. Namun sebaliknya apabila perencanaan kegiatan yang kurang matang akan berimplikasi pada pelaksanaan kegiatan yang tidak sesuai dengan perencanaannya. Perencanaan anggaran yang tidak baik sering menimbulkan hambatan dalam pelaksanaannya, sehingga harus direvisi atau bahkan tidak dapat direalisasi sama sekali. Perencanaan anggaran juga memberi kontribusi bagi penyerapan anggaran pemerintah daerah. Penelitian Suwarni (2018) menemukan bahwa faktor-faktor mempengaruhi keterlambatan penyerapan anggaran di Kota Surabaya, hasilnya menunjukkan bahwa salah satu faktor penyebab utama rendahnya penyerapan anggaran lemahnya perencanaan anggaran.

Hasil penelitian Setyawan (2016) tentang analisis keterlambatan penyerapan anggaran belanja satuan kerja kementrian/lembaga di wilayah pembayaran kppn bojonegoro tahun anggaran 2018 menemukan bahwa faktor perencanaan anggaran merupakan faktor yang paling dominan dalam kecenderungan keterlambatan penyerapan anggaran belanja. Sejalan dengan 
hasil penelitian Herriyanto (2012), Priatno (2013), Malahayati (2015), Zarinah (2016), Anfujatin (2016), Mutmainna (2017), Widianingrum (2017) dan Iqbal (2018) menyatakan bahwa faktor perencanaan berpengaruh terhadap penyerapan anggaran. Berbeda dengan Rifai (2016) dan Halim (2018) yang menunjukkan bahwa perencanaan tidak berpengaruh terhadap penyerapan anggaran. Berdasarkan ketidakkonsistenan hasil penelitian yang telah ada maka penelitian ini kembali dilakukan dengan tujuan untuk menguji kembali pengaruh perencanaan anggaran terhadap penyerapan anggaran, maka dapat dirumuskan hipotesis sebagai berikut:

H3: Perencanaan anggaran berpengaruh positif terhadap penyerapan

\section{Hubungan Sumber Daya Manusia dengan Penyerapan Anggaran}

Sumber daya manusia yang kompeten akan menjadi kelebihan tersendiri bagi organisasi pemerintah sekaligus sebagai pendukung daya saing pada era globalisasi dalam menghadapi lingkungan serta kondisi sosial masyarakat yang senantiasa mengalami perubahan dinamis (Putri, 2014). Sebaliknya, apabila suatu organisasi memiliki sumber daya manusia yang kurang kompeten akan berakibat pada menurunnya pencapaian tujuan organisasi.

Penelitian yang dilakukan oleh Anfujatin (2016) tentang analisis faktor-faktor yang menyebabkan rendahnya penyerapan anggaran belanja pada skpd kabupaten tuban menunjukkan bahwa sumber daya manusia mempengaruhi penyerapan anggaran. Terdapat pengaruh positif signifikan kompetensi sumber daya manusia (SDM) terhadap penyerapan anggaran. Hasil ini didukung juga Herryanto (2012), Putri (2014), Nugroho (2017) dan Mutmainna (2017). Berbeda dengan penelitian yang dilakukan Alumbida (2016), Nugroho (2017) dan Alimuddin (2018) yang menyatakan sebaliknya bahwa faktor sumber daya manusia tidak mempunyai pengaruh terhadap penyerapan anggaran. Berdasarkan ketidakkonsistenan hasil penelitian yang telah ada maka penelitian ini kembali dilakukan dengan tujuan untuk menguji kembali pengaruh sumber daya manusia terhadap penyerapan anggaran, maka dapat dirumuskan hipotesis sebagai berikut:

H4: Sumber daya manusia berpengaruh positif terhadap penyerapan anggaran

\section{Hubungan Pengadaan Barang/Jasa dengan Penyerapan Anggaran}

Mayoritas lambatnya serapan anggaran terjadi dikarenakan proses tender yang memakan waktu beberapa bulan, hal ini dikarenakan ada beberapa proses teknis ada beberapa proses teknis dan non teknis yang harus dijalankan dan harus melalui prosedur-prosedur yang sudah ditetapkan oleh aturan UU (Handayani, 2017). Lambatnya proses lelang ditambah lagi konflik-konflik yang terjadi selama proses tender berlangsung semakin memperparah lamanya waktu yang dibutuhkan untuk implementasi anggaran.

Matowardojo (2011) menjelaskan salah satu kendala utama dalam penyerapan anggaran yang lambat karena proses pelaksanaan pengadaan barang/jasa yang tidak terkoordinasi dengan baik. Senada dengan penelitian Priatno (2013) tentang analisis faktor-faktor yang mempengaruhi penyerapan anggaran pada satuan kerja lingkup pembayaran kppn blitar bahwa pengadaan barang/jasa berpengaruh terhadap penyerapan anggaran. Senada dengan penelitian yang dilakukan Setyawan (2016), Gogala (2016) dan Alimuddin (2018). Hal ini membuktikan bahwa pengadaan barang/jasa berpengaruh positif terhadap penyerapan anggaran. Dapat diartikan semakin baik pengadaan barang/jasa yang dilaksanakan makan akan semakin baik pula penyerapan anggaran di suatu OPD. Namun berbeda dengan penelitian yang dilakukan Nugroho dan Sanjaya (2018) yang menyatakan sebaliknya bahwa pengadaan barang/jasa tidak berpengaruh terhadap penyerapan anggaran. Berdasarkan dari hubungan diatas dan tidak konsistennya hasil penelitian yang telah ada, maka didapat hipotesis sebagai berikut : 
H5 : Pengadaan barang/jasa berpengaruh positif terhadap penyerapan anggaran

\section{Kerangka konseptual}

Untuk memudahkan memahami faktor-faktor yang mempengaruhi penyerapan anggaran belanja maka penulis menyusun kerangka konseptual sebagai berikut:

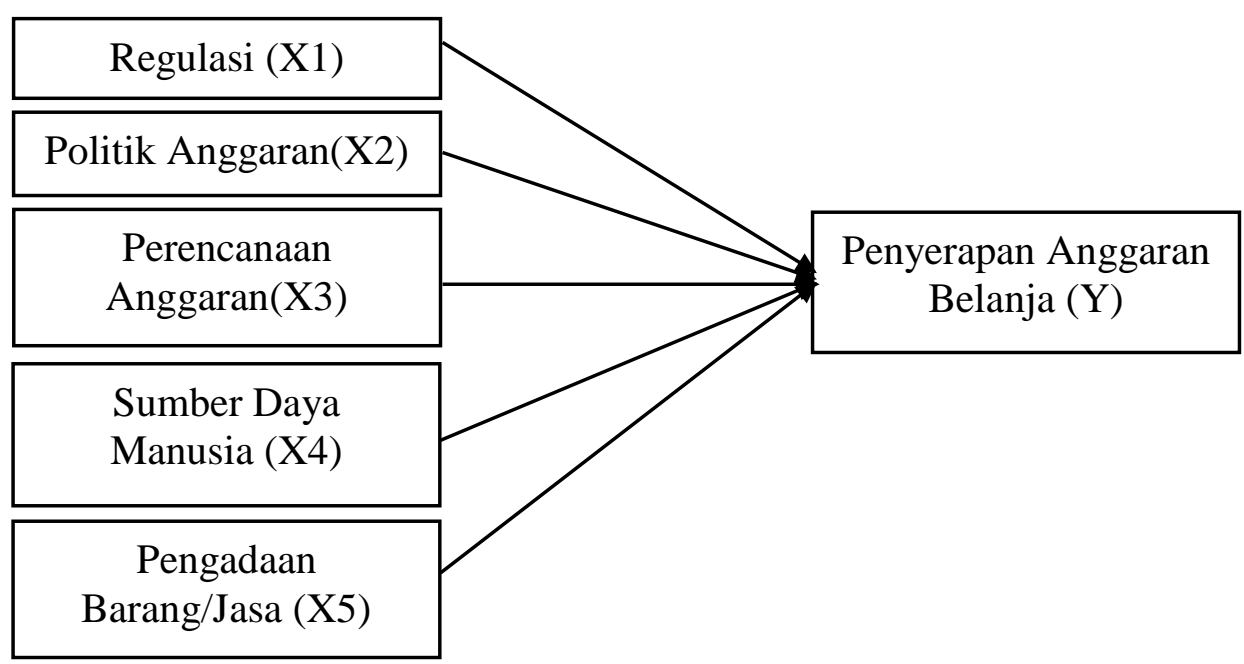

\section{METODE PENELITIAN}

\section{Jenis Penelitian}

Jenis penelitian ini tergolong penelitian kausalitas. Penelitian kausalitas bertujuan untuk mengetahui hubungan serta pengaruh variabel independen terhadap variabel dependen.

\section{Populasi dan Sampel}

Populasi adalah seluruh kumpulan elemen yang menunjukkan ciri-ciri tertentu yang dapat digunakan dengan membuat kesimpulan. Populasi pada penelitian ini adalah 39 OPD Provinsi Sumatera Barat. Berdasarkan data yang diperoleh dari Dinas Pengelolaan Keuangan Daerah Provinsi Sumatera Barat yang terdiri dari Dinas, Badan, Sekretariat dan Inspektorat. Pengambilan sampel dalam penelitian ini dilakukan dengan teknik purposive sampling yaitu pemilihan sampel berdasarkan kriteria tertentu.

\section{Jenis dan Teknik Pengumpulan Data}

Jenis data yang digunakan dalam penelitian ini adalah data primer dan data sekunder. Teknik pengumpulan data yang dilakukan dalam penelitian ini menggunakan kuesioner terstruktur terdiri dari pertanyaan tertutup berupa suatu pernyataan yang diberikan kepada responden untuk diisi berdasarkan pendapat masing-masing. Dari data responden diatas, maka peneliti akan mengajukan 4 buah kuesioner kepada 39 OPD Provinsi Sumatera Barat. Sehingga total kuesioner yang akan disebarkan adalah sejumlah 156 kuesioner. 


\section{HASIL DAN PEMBAHASAN}

Tabel 1.

Deskriptif Statistik

\begin{tabular}{|l|c|c|c|c|c|}
\hline & $\mathrm{N}$ & Minimum & Maximum & Mean & Std. Deviation \\
\hline Regulasi & 135 & 24 & 44 & 33,32 & 3,882 \\
Politik Anggaran & 135 & 8 & 20 & 14,02 & 2,806 \\
Perencanaan Anggaran & 135 & 7 & 25 & 18,74 & 3,112 \\
Sumber Daya Manusia & 135 & 8 & 20 & 16,68 & 2,874 \\
Pengadaan Barang/Jasa & 135 & 14 & 40 & 31,43 & 4,370 \\
Penyerapan Anggaran & 135 & 11 & 25 & 19,82 & 3,027 \\
Valid N (listwise) & 135 & & & & \\
\hline
\end{tabular}

Dapat dilihat bahwa nilai rata-rata (mean) penyerapan anggaran sebagai variabel dependen sebesar 19,82 dengan standar deviasi sebesar 3,027. Nilai maksimum dan minimum penyerapan anggaran adalah 25 dan 11. Variabel independen pertama dalam penelitian ini adalah regulasi memiliki nilai rata-rata sebesar 33,32 dengan standar deviasi 3,882. Nilai maksimum dan minimum pada variabel regulasi ini adalah 44 dan 24 . Variabel independen yang kedua adalah politik anggaran memiliki nilai rata-rata sebesar 14,02 dengan standar deviasi 2,806. Nilai maksimum dan minimum variabel politik anggaran adalah sebesar 20 dan 8 . Selanjutnya variabel independen yang ketiga adalah perencanaan anggaran memiliki nilai rata-rata sebesar 18,74 dan standar deviasi 3,112. Variabel perencanaan anggaran memiliki nilai maksimum dan minimum sebesar 25 dan 7.

Selanjutnya variabel independen yang keempat adalah sumber daya manusia memiliki nilai rata-rata sebesar 16,68 dan standar deviasi 2,874. Variabel sumber daya manusia memiliki nilai maksimum dan minimum sebesar 20 dan 8. Dan variabel independen yang kelima adalah pengadaan barang/jasa memiliki nilai rata-rata sebesar 31,43 dan standar deviasi 4,370. Variabel pengadaan barang/jasa memiliki nilai maksimum dan minimum sebesar 40 dan 14 . Hal ini menunjukkan bahwa data dalam penelitian ini beragam dan bervariasi dikarenakan standar deviasi yang dimiliki oleh semua variabel besar dari 0 .

Tabel 2.

Analisis Model Persamaan

\begin{tabular}{|c|c|c|c|c|c|}
\hline \multirow[b]{2}{*}{ Model } & \multicolumn{2}{|c|}{$\begin{array}{c}\text { Unstandardized } \\
\text { Coefficients }\end{array}$} & \multirow{2}{*}{$\begin{array}{c}\text { Standardized } \\
\text { Coefficients } \\
\text { Beta }\end{array}$} & \multirow[b]{2}{*}{$\mathrm{t}$} & \multirow[b]{2}{*}{ Sig. } \\
\hline & $\mathrm{B}$ & Std. Error & & & \\
\hline $1 \quad$ (Constant) &,- 324 & 2,033 & &,- 159 & ,874 \\
\hline Regulasi &, 156 &, 060 & ,200 & 2,587 &, 011 \\
\hline Politik Anggaran & ,032 & 075 & ,029 &, 421 & 674 \\
\hline Perencanaan Anggaran & 222 & ,078 & 229 & 2,856 &, 005 \\
\hline Sumber Daya Manusia &, 110 & ,071 & ,104 & 1,542 &, 126 \\
\hline Pengadaan Barang/Jasa & ,270 &, 052 & ,390 & 5,168 &, 000 \\
\hline
\end{tabular}

a. Dependent Variable: Penyerapan Anggaran

Berdasarkan tabel di atas dapat dianalisis model persamaan sebagai berikut:

$$
Y=-0,324+0,156 X 1+0,32 X 2+0,222 \times 3+0,110 X 4+0,270 X 5+e
$$




$$
\begin{aligned}
& \text { Keterangan: } \\
& \mathrm{Y} \quad=\text { Penyerapan Anggaran } \\
& \mathrm{X} 1=\text { Regulasi } \\
& \mathrm{X} 2=\text { Politik Anggaran } \\
& \text { X3 = Perencanaan Anggaran } \\
& \text { X4 = Sumber Daya Manusia } \\
& \text { X5 = Pengadaan Barang/Jasa }
\end{aligned}
$$

Tabel 3.

Uji Adjusted $R^{2}$

\begin{tabular}{|l|r|r|r|r|}
\hline Model & R & R Square & $\begin{array}{c}\text { Adjusted R } \\
\text { Square }\end{array}$ & $\begin{array}{c}\text { Std. Error of the } \\
\text { Estimate }\end{array}$ \\
\hline 1 & $.706^{\mathrm{a}}$ & .498 & .478 & 2.186 \\
\hline
\end{tabular}

a. Predictors: (Constant), Pengadaan Barang/Jasa, Regulasi,

Sumber Daya Manusia, Politik Anggaran, Perencanaan

Anggaran

b. Dependent Variable: Penyerapan Anggaran

Dari tampilan tabel di atas besarnya Adjusted $R$ Square adalah 47,8\%. Hal ini mengidentifikasikan bahwa konstribusi variabel regulasi, politik anggaran, perencanaan anggaran, sumber daya manusia dan pengadaan barang/jasa adalah sebesar $47,8 \%$, sedangkan $52,2 \%$ lainnya ditentukan oleh faktor lain di luar model yang tidak terdeteksi dalam penelitian.

Tabel 4.

Uji F

\begin{tabular}{|ll|r|r|r|r|r|}
\hline Model & Sum of Squares & Df & Mean Square & F & \multicolumn{1}{c|}{ Sig. } \\
\hline 1 & Regression & 611.283 & 5 & 122.257 & 25.584 & $.000^{\mathrm{b}}$ \\
& Residual & 616.450 & 129 & 4.779 & & \\
Total & 1227.733 & 134 & & & \\
\hline
\end{tabular}

a. Dependent Variable: Penyerapan Anggaran

b. Predictors: (Constant), Pengadaan Barang/Jasa, regulasi, sumber daya manusia, politik anggaran, perencanaan anggaran

Hasil uji pada tabel diatas diperoleh nilai $\mathrm{F}=25,587$ dengan nilai signifikansi sebesar $\mathrm{P}$ value $=0,000$ yang lebih kecil dari $\alpha=0,05$. Jadi dapat disimpulakn bahwa model penelitian yang digunakan dianggap layak uji dan ketiga variabel mampu menjelaskan penyerapan anggaran pada OPD Provinsi Sumatera Barat.

\section{Hipotesis 1}

Hipotesis pertama dalam penelitian ini adalah regulasi berpengaruh positif terhadap penyerapan anggaran belanja. Berdasarkan pada hasil analisis statistik dalam penelitian ini ditemukan bahwa hipotesis pertama (H1) diterima dan disimpulkan bahwa regulasi berpengaruh signifikan positif terhadap penyerapan anggaran belanja. Hal ini dapat dilihat dari hasil pengujian secara parsial nilai signifikansi $0,011<0,05$ dan koefisien $\beta$ bernilai positif yaitu sebesar 0,156 .

Jika dilihat dari tabel distribusi frekuensi variabel, rata-rata Tingkat Capaian Responden (TCR) menunjukkan kategori baik dengan angka 74,04\% berdasarkan data tersebut penerapan regulasi pada OPD Provinsi Sumatera Barat sudah terlaksana dengan baik dan mempengaruhi 
penyerapan anggaran. Sehingga tingkat capaian responden yang baik ini dapat membuktikan bahwa regulasi berpengaruh signifikan positif terhadap penyerapan anggaran.

Hasil penelitian ini sejalan dengan penelitian yang telah dilakukan oleh Alimuddin (2018) yang menemukan regulasi berpengaruh positif dan signifikan terhadap penyerapan anggaran, kesimpulan yang diperoleh mengindikasikan bahwa kejelasan regulasi mulai dari tahap perencanaan hingga SOP berhubungan signifikan dengan penyerapan anggaran. Selain itu hasil pengujian hipotesis dalam penelitian ini juga di dukung dengan penelitian yang dilakukan oleh Ridani (2015) dan Widianingrum (2017) yang juga membuktikan bahwa faktor regulasi merupakan salah satu faktor yang mempengaruhi penyerapan anggaran. Namun penelitian ini tidak mendukung penelitian yang dilakukan oleh Rifai (2016) yang membuktikan sebaliknya bahwa regulasi tidak berpengaruh terhadap penyerapan anggaran pada SKPD Pemprov NTB.

Secara teori menurut (Bastian, 2010) dapat dijelaskan bahwa regulasi publik adalah ketentuan yang harus dijalankan dan dipatuhi dalam proses pengelolaan organisasi. Hasil penelitian ini sejalan dengan teori stakeholder yang mana pemerintah daerah sebagai stakeholder yang pengaruhnya cukup signifikan terhadap pembangunan didaerah oleh karena itu pemerintah mengeluarkan sebuah regulasi untuk mengendalikan kegiatan pada pemerintahan. Sehingga segala tindakan pengguna anggaran pada OPD dalam proses penyerapan anggaran disebabkan kebijakan atau aturan dalam pengelolaan anggaran yang sudah berjalan dan terlaksana dengan baik.

\section{Hipotesis 2}

Hipotesis kedua dalam penelitian ini adalah politik anggaran berpengaruh positif terhadap penyerapan anggaran belanja. Berdasarkan pada hasil analisis statistik dalam penelitian ini ditemukan bahwa hipotesis kedua (H2) ditolak dan disimpulkan bahwa politik anggaran tidak berpengaruh terhadap penyerapan anggaran belanja. Hal ini dapat dilihat dari hasil pengujian secara parsial nilai signifikansi $0,674>0,05$ dan koefisien $\beta$ bernilai positif yaitu sebesar 0,032 . Jika dilihat dari tabel distribusi frekuensi variabel, rata-rata Tingkat Capaian Responden (TCR) menunjukkan kategori baik dengan angka 70,11.

Dominan jawaban responden antara lain adalah anggaran yang disusun oleh OPD berdasarkan asas keadilan, namun tingkat capaian responden yang baik ini tidak dapat membuktikan bahwa politik anggaran berpengaruh terhadap penyerapan anggaran. Hal ini berarti politik anggaran tidak menunjukkan bahwa dalam pelaksanaan anggaran yang tidak sesuai dengan kepentingan politik atau pelaksanaan yang diajukan tidak sesuai dengan prioritas yang disepakati bersama. Oleh karena itu politik anggaran tidak mempengaruhi penyerapan anggaran.

Hasil penelitian ini tidak sejalan dengan penelitian dengan penelitian yang telah dilakukan oleh Sanjaya (2018) yang membuktikan bahwa politik anggaran berpengaruh terhadap penyerapan anggaran. Akan tetapi penelitian ini sejalan dengan penelitian yang dilakukan Handayani (2017) yang menemukan bahwa politik anggaran tidak berpengaruh terhadap penyerapan anggaran.

Secara teori menurut Mardiasmo (2002) dapat dijelaskan bahwa anggaran merupakan alat politik sebagai bentuk komitmen eksekutif dan kesepakatan legislatif atas penggunaan dana publik untuk kepentingan tertentu. Dalam teori stakeholder yang mana pemerintah daerah sebagai stakeholder yang pengaruhnya cukup signifikan terhadap pembangunan didaerah, namun hal ini dipengaruhi oleh berbagai proses politik. Hal ini disebabkan karena pengambilan keputusan harus menentukan prioritas yang lebih utama dibandingkan prioritas lainnya. Namun dalam penelitian ini politik anggaran tidak mendukung dalam teori stakeholder. 


\section{Hipotesis 3}

Hipotesis ketiga dalam penelitian ini adalah perencanaan anggaran berpengaruh positif terhadap penyerapan anggaran. Berdasarkan pada hasil analisis statistik dalam penelitian ini ditemukan bahwa hipotesis kedua (H3) diterima dan disimpulkan bahwa perencanaan anggaran berpengaruh terhadap penyerapan anggaran belanja. Hal ini dapat dilihat dari hasil pengujian secara parsial nilai signifikansi $0,005<0,05$ dan koefisien $\beta$ bernilai positif yaitu sebesar 0,222 .

Jika dilihat dari tabel distribusi frekuensi variabel, rata-rata Tingkat Capaian Responden (TCR) menunjukkan kategori baik dengan angka 74,96 berdasarkan data tersebut hal ini bermakna bahwa perencanaan anggaran sudah berjalan dengan baik sehingga tidak akan mengganggu tingkat penyerapan anggaran, ini berarti bahwa pengelola anggaran dalam merencanakan program kerja/kegiatan dalam satu tahun anggaran sudah berjalan dengan baik, sehingga target penyerapan anggaran dapat tercapai. Sehingga tingkat capaian responden yang baik ini dapat membuktikan bahwa perencanaan anggaran berpengaruh signifikan positif terhadap penyerapan anggaran.

Dalam teori stakeholder pemerintah daerah memiliki beberapa stakeholder yang memiliki hubungan timbal balik masing-masing pihak yang akan berdampak antara yang satu dengan yang lainnya dalam mencapai tujuan tertentu. Pemerintah sebagai stakeholder yang pengaruhnya cukup signifikan terhadap pembangunan di daerah, sehingga dengan adanya sumber daya yang ada akan mampu memajukan pembangunan secara maksimal dengan pelaksanaan sasaran program yang tepat melalui perencanaan yang optimal dapat mempermudah pelaksanaa kegiatan.

Hasil penelitian ini sejalan dengan penelitian yang dilakukan Setyawan (2016) yang menyimpulkan bahwa faktor perencanaan merupakan faktor yang paling dominan dalam kecenderungan keterlambatan penyerapan anggaran belanja. Kesimpulan yang diperoleh memperkuat hasil penelitian sebelumnya oleh Herriyanto (2012), Malahayati (2015), Zarinah (2015), dan Iqbal (2018) bahwa semakin baik perencanaan maka penyerapan anggaran akan lebih baik sehingga faktor perencanaan anggaran berpengaruh terhadap penyerapan anggaran.

Akan tetapi hasil ini tidak sejalan dengan penelitian yang dilakukan oleh Rifai (2016) dan Halim (2018) yang menunjukkan bahwa perencanaan anggaran tidak berpengaruh terhadap penyerapan anggaran yang menemukan perencanaan anggaran mempunyai pengaruh signifikan negatif terhadap penyerapan anggaran yang menunjukkan bahwa semakin tidak baik perencanaan anggaran yang dilakukan oleh aparat pemerintahan maka semakin rendah tingkat penyerapan anggaran.

\section{Hipotesis 4}

Hipotesis keempat dalam penelitian ini adalah sumber daya manusia berpengaruh positif terhadap penyerapan anggaran belanja. Berdasarkan pada hasil analisis statistik dalam penelitian ini ditemukan bahwa hipotesis keempat (H4) ditolak dan disimpulkan bahwa sumber daya manusia tidak berpengaruh terhadap penyerapan anggaran belanja. Hal ini dapat dilihat dari hasil pengujian secara parsial nilai signifikansi $0,126>0,05$ dan koefisien $\beta$ bernilai positif yaitu sebesar 0,110 .

Jika dilihat dari tabel distribusi frekuensi variabel, rata-rata Tingkat Capaian Responden (TCR) menunjukkan kategori sangat baik dengan angka $83,41 \%$ berdasarkan data tersebut sumber daya manusia memiliki indikator dominan yaitu sumber daya manusia yang bekerja sesuai dengan keahlian masing-masing, yang berarti menjadi kelebihan tersendiri oleh organisasi pemerintah dalam meningkatkan kinerja dalam mencapai tujuan, namun dengan tingkat capaian 
responden yang sangat baik ini tidak dapat membuktikan bahwa sumber daya manusia berpengaruh signifikan terhadap penyerapan anggaran.

Temuan penelitian ini tidak mendukung konsep sumber daya manusia pada teori stakeholder yaitu pemerintah sebagai stakeholder memiliki peranan sumber daya manusia yang sesuai dengan kompetensi dan pembagian kerja yang tepat sesuai spesialisasinya sehingga tujuan yang direncanakan dapat tercapai

Hasil penelitian ini sejalan dengan penelitian yang telah dilakukan oleh Alumbida (2016), Nugroho (2017) dan Alimuddin (2018) yang membuktikan bahwa sumber daya manusia tidak berpengaruh terhadap penyerapan anggaran. Namun Penelitian ini tidak sejalan dengan penelitian yang dilakukan oleh Herriyanto (2012) tentang faktor-faktor yang memengaruhi keterlambatan penyerapan anggaran belanja pada satuan kerja Kementerian/Lembaga di wilayah Jakarta memberikan hasil bahwa sumber daya manusia memiliki pengaruh yang signifikan terhadap keterlambatan penyerapan anggaran dan Penelitian Anfujatin (2016) tentang analisis faktor-faktor yang menyebabkan rendahnya penyerapan anggaran belanja pada skpd kabupaten tuban yang menyatakan bahwa sumber daya manusia berpengaruh terhadap penyerapan anggaran. Yang didukung oleh penelitian yang dilakuakn Setyawan (2016), Putri (2014), dan Mutmainna (2017).

\section{Hipotesis 5}

Hipotesis kelima dalam penelitian ini adalah pengadaan barang/jasa berpengaruh positif terhadap penyerapan anggaran belanja. Berdasarkan pada hasil analisis statistik dalam penelitian ini ditemukan bahwa hipotesis kelima (H5) diterima dan disimpulkan bahwa pengadaan barang/jasa berpengaruh signifikan positif terhadap penyerapan anggaran belanja. Hal ini dapat dilihat dari hasil pengujian secara parsial nilai signifikansi $0,000<0,05$ dan koefisien $\beta$ bernilai positif yaitu sebesar 0,270 .

Jika dilihat dari tabel distribusi frekuensi variabel, rata-rata Tingkat Capaian Responden (TCR) menunjukkan kategori baik dengan angka 78,59, berdasarkan data tersebut variabel pengadaan barang/jasa dengan indikator efisiensi dan efektifitas, akuntabilitas dan kesesuaian peraturan memberikan pengaruh signifikan positif terhadap penyerapan anggaran sudah berjalan secara efektif dan efisien selama proses penyerapan anggaran. Sehingga tingkat capaian responden yang baik ini dapat membuktikan bahwa pengadaan barang/jasa berpengaruh signifikan positif terhadap penyerapan anggaran.

Teori stakeholder menjelaskan bahwa pemerintah daerah memiliki hubungan timbal balik masing-masing pihak yang akan memiliki dampak antara yang satu dengan yang lain dalam mencapai tujuan tertentu, pemerintah sebagai stakeholder yang pengaruhnya cukup signifikan terhadap pembangunan di daerah memberikan pelayanan atas kebutuhan masyarakat dengan proses pengadaan barang/jasa secara online yang merupakan salah satu jalan untuk mempercepat penyerapan anggaran.

Penelitian ini sejalan dengan penelitian sebelumnya yang dilakukan oleh Priatno (2013) yang menyatakan bahwa pengadaan barang/jasa berpengaruh signifikan terhadap penyerapan anggaran.Senada dengan itu penelitian yang dilakukan oleh Setyawan (2016), Gogala (2016) dan Alimuddin (2018) juga menyatakan bahwa faktor yang mempengaruhi penyerapan anggaran disebabkan oleh faktor pengadaan barang/jasa. Namun hasil ini tidak sejalan dengan penelitian yang dilakukan oleh Nugroho (2017) dan Sanjaya (2018) yang menyatakan bahwa pengadaan barang/jasa tidak mempengaruhi penyerapan anggaran. 


\section{KESIMPULAN DAN SARAN \\ Kesimpulan}

Penelitian ini bertujuan untuk melihat pengaruh regulasi, politik anggaran, perencanaan anggaran, sumber daya manusia dan pengadaan barang/jasa berpengaruh positif signifikan terhadap penyerapan anggaran belanja pada OPD Provinsi Sumatera Barat. Berdasarkan hasil penelitian dan pengujian hipotesis yang telah dilakukan maka hasil penelitian ini dapat disimpulkan sebagai berikut :

1. Regulasi, Perencanaan Anggaran dan Pengadaan Barang/ Jasa dalam pengujian hipotesis berpengaruh positif signifikan terhadap penyerapan anggaran belanja pada OPD Provinsi Sumatera Barat.

2. Sedangkan Politik Anggaran dan Sumber Daya Manusia dalam pengujian hipotesis tidak berpengaruh positif signifikan terhadap penyerapan anggaran belanja pada OPD Provinsi Sumatera Barat.

\section{Keterbatasan Penelitian}

Penelitian yang telah dilakukan masih banyak memiliki kekurangan dan keterbatasan. Keterbatasan dalam penelitian adalah sebagai berikut :

1. Nilai Adjusted $\mathrm{R}^{2}$ yang rendah hanya sebesar $47,8 \%$ menunjukkan bahwa masih banyak variabel lain yang memiliki kontribusi besar dalam mempengaruhi penyerapan anggaran.

2. Penelitian ini hanya meneliti pada OPD Provinsi Sumatera Barat, sehingga untuk pemerintah provinsi lain yang berbeda dapat dimungkinkan terjadinya perbedaan kesimpulan.

\section{Saran}

Berdasarkan kesimpulan dan keterbatasan yang telah diuraikan, maka saran-saran yang dapat diberikan adalah sebagai berikut :

1. Bagi organisasi. Diharapkan dapat menjadi bahan acuan dalam upaya meningkatkan penyerapan anggaran Provinsi Sumatera Barat, meningkatkan regulasi, politik anggaran, perencanaan anggaran dan sumber daya manusia dalam sebuah OPD.

2. Bagi penelitian selanjutnya, dapat menambah variabel lain yang diidentifikasi dapat mempengaruhi nilai perusahaan karena rendahnya nilai Adjusted $R^{2}$ yang dihasilkan dalam penelitian ini. Variabel lain, seperti: pelaksanaan anggaran, komitmen oganisasi, faktor administrasi, dan variabel lainnya

\section{DAFTAR PUSTAKA}

Abdullah, S. dan Nazri, R. (2010). Serapan Anggaran Pemerintah Daerah Faktor-Faktor Yang Mempengaruhinya, Studi pada Pemerintah Daerah Kabupaten/Kota di Aceh. Tesis (Tidak Dipublikasikan). Universitas Syiah Kuala.

Alimuddin. (2018). Analisis Penyerapan Anggaran di Perguruan Tinggi Negeri (PTN) dan Kopertis Makassar. Tesis. Universitas Hasanuddin.

Alumbida, S., dan Ilat. (2016). Pengaruh Perencanaan, Kapasitas Sumber Daya Manusia dan Komitmen Organisasi terhadap Penyerapan Anggaran Belanja Daerah Pada Pemerintah Kabupaten Kepulauan Talaud. Universitas Sam Ratulanggi.

Anfujatin. (2016). Analisis Faktor-faktor yang Menyebabkan Rendahnya Penyerapan Anggaran Belanja Pada SKPD Kabupaten Tuban. Jurnal Administrasi Publik. Universitas 17 Agustus Surabaya. 
Bastian, I. (2006). Sistem Perencanaan dan Penganggaran Pemerintah Daerah. Jakarta: Salemba Empat.

Bastian, I. (2010). Akuntansi Sektor Publik Suatu Pengantar. Jakarta: Salemba Empat.

BPKP (2012). Mencari Solusi bagi Serapan yang Tersumbat. Jakarta: Warta Pengawasan.

Dwiyana, N. (2017). Faktor-Faktor yang Mempengaruhi Penyerapan Anggaran Satuan Kerja Perangkat Daerah Pemerintah Kota Medan dengan Monitoring dan Evaluasi Sebagai Variabel Moderating. Tesis. Universitas Sumatera Utara.

Ghozali, I. dan Chariri, A. (2007). Teori Akuntansi. Semarang: Badan Penerbit Universitas Diponegoro.

Halim, A. (2014). Manajemen Keuangan Sektor Publik problematika penerimaan dan pengeluaran pemerintah. Jakarta: Salemba Empat.

Handayani, C. H. (2017). Analisis Faktor-Faktor yang Mempengaruhi Serapan Anggaran SKPD di Provinsi Sumatera Utara Tahun 2014 - 2015 dengan SiLPA sebagai Variabel Moderating. Jurnal SNA.

Herriyanto, H. (2012). Faktor-faktor yang Mempengaruhi Keterlambatan Penyerapan Anggaran Belanja pada Satuan Kerja Kementerian/Lembaga di Wilayah Jakarta. Jakarta. Tesis. Universitas Indonesia

Iqbal, M. (2018). Pengaruh Perencanaan Anggaran dan Kompetensi Sumber Daya Manusia terhadap Penyerapan Anggaran dengan Komitmen Organisasi sebagai Pemoderasi. Tesis. Universitas Hasanuddin

Kaharuddin. (2011). Analisis Faktor-Faktor yang Mempengaruhi Penyerapan Belanja Daerah di Kabupaten Sumbawa (Studi Kasus Belanja DAK bidang Pendidikan. Tesis (Tidak dipublikasikan). Universitas Sumatera Utara.

Kuncoro, M. (2013). Mudah Memahami dan Menganalisis Indikator Ekonomi. Yogyakarta : UPP STIM YKPN.

Kuswoyo, D. I. (2011). Analisis atas Faktor-Faktor yang Menyebabkan Terkonsentrasinya Penyerapan Anggaran Belanja di Akhir Tahun Anggaran: Studi pada Satuan Kerja di Wilayah KPPN Kediri. Tesis (Tidak Dipublikasikan). Universitas Gadjah Mada.

Mardiasmo. (2002). Akuntansi Sektor Publik. Yogyakarta: Andi.

Mardiasmo. (2009). Akuntansi Sektor Publik. Yogyakarta. Andi.

Ministry of Finance, Planning and Economic Development of Uganda. (2011). Absorptive Capacity Constraints: The Causes and Implications for Budget Execution. Development Policy and Research Department.

Mutmainna. (2017). Faktor-Faktor yang Mempengaruhi Penyerapan Anggaran Satuan Kerja Perangkat Daerah Pemerintah Provinsi Sulawesi Selatan. Jurnal Akuntansi Riset.

Ngurah, A.I.G. (2015). Addendum Kontrak Pemborongan Perspektif Hukum Perjanjian di Indonesia. Jurnal Advokasi.

Nordiawan, D. dan Hertianti, A. (2010). Akuntansi Sektor Publik, Edisi 2. Jakarta: Salemba Empat.

Nugroho, R. (2017). Faktor-Faktor yang Mempengaruhi Melonjaknya Penyerapan Anggaran Quartal IV Instansi Pemerintah (Studi Pada Badan Pendidikan dan Pelatihan Keuangan). Jurnal BPPK..

Priatno, P. A \& Khusaini, M. (2013). Analisis Faktor-Faktor yang Mempengaruhi Penyerapan Anggaran pada Satuan Kerja Lingkup Pembayaran KPPN Blitar. E-Journal Universitas Brawijaya 
Putri, C. T. (2014). Analisis Faktor-faktor yang Mempengaruhi Penyerapan Anggaran pada Satuan Kerja Perangkat Daerah di Pemerintah Provinsi Bengkulu. Skripsi. Universitas Bengkulu.

Ridani, M. A. (2015). Analisis Penyerapan Anggaran Belanja Daerah Di Kabupaten Bulungan. Tesis. Universitas Gadjah Mada.

Rifai, A. dan Inapty, B. A. (2016). Analisis Faktor-Faktor yang Memengaruhi Keterlambatan Daya Serap Anggaran (Studi Empiris pada SKPD Pemprov NTB). Jurnal Ilmiah Akuntansi dan Bisnis.

Riyanto, A. (2012). Politik Anggaran Provinsi Jawa Tengah: Analisis Realisasi APBD Provinsi Jawa Tengah Tahun Anggaran 2008-2010. Jurnal Ilmu Politik Hubungan Internasional.

Rubin, I. S. (2000). The Politics Of Public Budgeting: Getting and spending, Browing and Balancing. New York: Chatham Houce Publishing.

Salamah, S. (2018). Strategi Penyerapan Anggaran Pendapatan dan Belanja (APBD) Pemerintah Provinsi Jawa Tengah. Economics Development Analysis Journal.

Sanjaya, T. (2018). Pengaruh Regulasi Keuangan Daerah, Politik Anggaran, Pelaksanaan Pengadaan Barang/Jasa terhadap Penyerapan Anggaran Pada OPD Provinsi Sumatera Barat. Skripsi. Universitas Negeri Padang.

Seftianova, R. dan Adam, H. (2013). Pengaruh Kualitas DIPA dan Akurasi Perencanaan Kas terhadap Kualitas Penyerapan Anggaran pada Satker Wilayah KPPN Malang. Jurnal Riset Akuntansi \& Komputerisasi Akuntansi (JRAK).

Setyawan, A. (2014). Analisis Keterlambatan Penyerapan Anggaran Belanja Satuan Kerja Kementerian/Lembaga Di Wilayah Pembayaran KPPN Bojonegoro. Tesisi. Universitas Airlangga.

Spencer, L. and Spencer, S. M. (1993). Competence at Work, Models For Superior Performance. Canada : John Wiley \& Sons, Inc.

Sudarwati, N. (2017). Identifikasi Faktor-Faktor Penumpukan Realisasi Anggaran Belanja Di Akhir Tahun (Studi Kasus pada Balai Penelitian dan Pengembangan Lingkungan Hidup dan Kehutana Manado). Jurnal Riset Akuntansi dan Auditing "Goodwill”.

Sutrisno, E. (2009). Manajemen Sumber Daya Manusia Edisi pertama. Jakarta: Kencana Prenada Media Group.

Suwarni, D. E. (2018). Faktor-Faktor Yang Mempengaruhi Keterlambatan Penyerapan Anggaran Pendapatan dan Belanja Daerah (APBD) di Kota Surabaya (Studi pada SKPD Dinas PU Bina Marga dan Pemantusan.Universitas Negeri Surabaya).

Ulum, I. (2009). Intellectual Capital: Konsep dan Kajian Empiris. Yogyakarta: Graha Ilmu.

Vega, J. (2007). An Analytical Model of Absorptive Capacity. Paper to be presented at The Druid Summer Conference on Appropriability, Proximity, Routines and Innovation.

Widianingrum, D. (2017). Faktor-Faktor Yang Mempengaruhi Penyerapan Anggaran Satuan Kerja Perangkat Daerah di Pemerintah Kabupaten Situbondo. Jurnal Bisnis dan Manajemen.

Zarinah, M. (2016). Pengaruh Perencanaan Anggaran dan Kualitas Sumber Daya Manusia terhadap Tingkat Penyerapan Anggaran Satuan Kerja Perangkat Daerah di Kabupaten Aceh Utara. Jurnal Magister Akuntansi. 